\section{Decreased intelligence in children and exposure to fluoride and arsenic in drinking water}

\author{
Disminución de la inteligencia en niños y \\ exposición al flúor y arsénico en el agua potable
}

\author{
${ }^{1}$ Facultad de Medicina, \\ Universidad Autónoma de \\ San Luis Potosí, San Luis \\ Potosí, México. \\ 2 Facultad de Psicología, \\ Universidad Autónoma de \\ San Luis Potosí, San Luis \\ Potosí, México. \\ Correspondence \\ J. Calderón \\ Departamento de Toxicología \\ Ambiental, Facultad de \\ Medicina, Universidad \\ Autónoma de San Luis Potosí. \\ Av. Venustiano Carranza \\ 2405, Col. Lomas los Filtros, \\ San Luis Potosí, \\ S.L.P. 78210 México. \\ calderoj@uaslp.mx
}

\begin{abstract}
Recent evidence suggests that fluoride (F) and arsenic (As) may adversely affect intelligence quotient (IQ) scores. We explore the association between exposure to $F$ and As in drinking water and intelligence in children. Three rural communities in Mexico with contrasting levels of $F$ and As in drinking water were studied: Moctezuma (F 0.8 $\pm 1.4 m g / L$; As 5.8 $1.3 \mu \mathrm{g} / \mathrm{L}$ ); Salitral (F 5.3 $\pm 0.9 \mathrm{mg} / \mathrm{L}$; As $169 \pm 0.9 \mu \mathrm{g} / \mathrm{L}$ ) and $5 \mathrm{de} \mathrm{Fe}$ brero (F $9.4 \pm 0.9 \mathrm{mg} / \mathrm{L}$; As $194 \pm 1.3 \mu \mathrm{g} / \mathrm{L}$ ). The final study sample consisted of 132 children from 6 to 10 years old. After controlling for confounders, an inverse association was observed between $F$ in urine and Performance, Verbal, and Full IQ scores ( $\beta$ values $=-13,-15.6,-16.9$, respectively). Similar results were observed for $F$ in drinking water $(\beta$ values $=-6.7,-11.2,-10.2$, respectively $)$ and $A$ s in drinking water ( $\beta$ values $=-4.30,-6.40$, -6.15 , respectively). The $p$-values for all cases were $<0.001$. A significant association was observed between As in urine and Full IQ scores ( $\beta=-5.72, p=0.003)$. These data suggest that children exposed to either F or As have increased risks of reduced IQ scores.
\end{abstract}

Fluorides; Arsenic; Potable Water; Neurotoxins; Intelligence

\author{
Diana Rocha-Amador 1 \\ Maria Elena Navarro 2 \\ Leticia Carrizales 1 \\ Raúl Morales 2 \\ Jaqueline Calderón 1
}

\section{Introduction}

Elevated concentration of naturally occurring fluoride (F) or arsenic (As) in drinking water is a worldwide problem. Many Asian and Latin American countries have reported concentrations of either F or As often exceeding the World Health Organization (WHO) guideline values of $1.5 \mathrm{mg} / \mathrm{L}$ and $10 \mu \mathrm{g} / \mathrm{L}$, respectively, or their prevailing national standards 1,2 . In many communities in the central and northern states of Mexico people are exposed to either $\mathrm{F}$ and/or As in drinking water $3,4,5,6$. According to data from the National Institute of Statistics Geography and Informatics (INEGI: http://www.inegi.gob. $\mathrm{mx} /$, accessed on 03/Sep/2006), approximately 14 million people live in risk areas in Mexico.

The health effects in humans associated with exposure to F (skeletal and dental fluorosis and reproductive effects) or As (skin, bladder, and lung cancer) are well documented 7,8. Also, the literature reports neurological consequences associated with exposure to F or As. In children, the most reported effect is on cognitive capacities, particularly intelligence reduction 9,10,11,12,13,14,15,16. Even in studies with methodological limitations, intelligence quotient (IQ) reduction is a consistent conclusion. The evidence of $\mathrm{F}$ and As neurotoxicity is supported by animal studies, which show cognitive deficits are associated with $\mathrm{F}$ exposure 17 , and behavioral changes (locomotor activity) and delayed learn- 
ing are associated with As exposure 18 . So far, the studies have evaluated only the individual effect of F or As on IQ, without taking into account that they may share the same source of exposure (drinking water, coal etc.). In Mexico many aquifers are polluted by F and/or As. Accordingly, considering that both contaminants have been shown to be neurotoxicants, the objective of this study was to explore the influence of both $\mathrm{F}$ and As on IQ in children living in three rural areas with contrasting levels of $\mathrm{F}$ and As.

\section{Methods}

\section{Study population}

All children attending the first through third grades in public schools in three rural areas in Mexico were screened for study eligibility through in-person interviews $(n=480)$. They included questions about age of the child, time of residence, and address. The locations of the communities are shown in Figure 1. Moctezuma and Salitral are located in the northwest region of San Luis Potosí State and 5 de Febrero is located in the central region of Durango State.
The three selected communities were similar in population and general demographic characteristics. Children who had lived in the area since birth and who were from 6 to 10 years old at the time of the study were eligible to participate ( $\mathrm{n}=308$ ). Of those eligible, 155 children were randomly selected for study participation. The response rate was $85 \%$. No significant differences in age, gender proportion, or time of residence were observed between study participants and non-participants.

\section{Neuropsychological evaluation}

The neuropsychological profile was assessed using the Wechsler Intelligence Scale for ChildrenRevised Mexican Version (WISC-RM). All tests were administered at school by a trained neuropsychologist who was masked to participant's $\mathrm{F}$ or As urine or water levels. A standardized version of the WISC-RM was administered 19. Ten different subtests were given to each child, five predominantly verbal (information, similarities, arithmetic, vocabulary, and comprehension) and five predominantly performance oriented (picture completion, picture arrangement, block design, object assembly, and coding). Raw scores

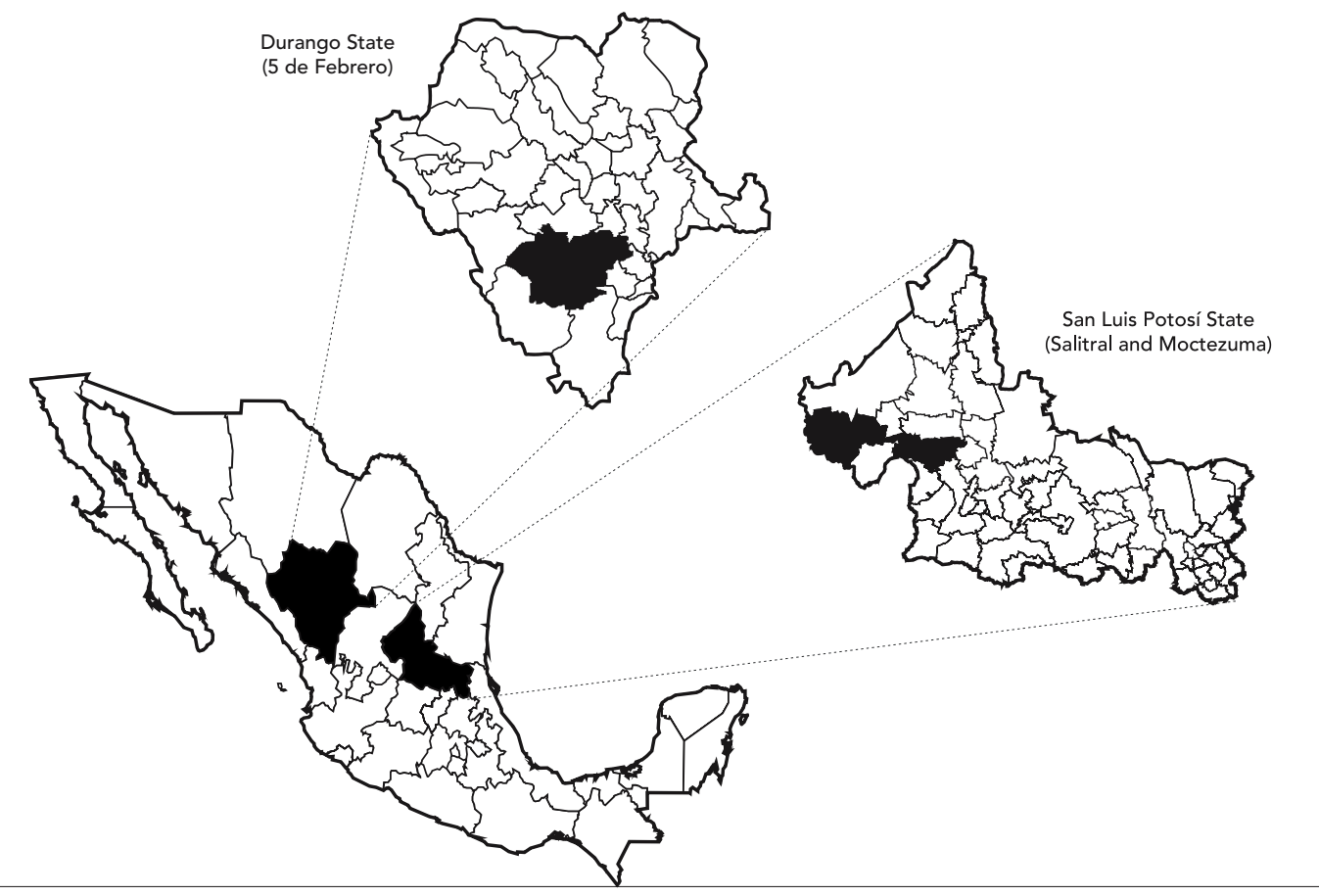


were age-adjusted and summed to yield conventional measures of full, verbal, and performance IQ scales.

\section{Environmental and biological analysis}

Tap water and bottled water (where available) samples were collected in polyethylene bottles at each child's home the same day of biological monitoring. $F$ levels were quantified by adding TISAB buffer to the samples with a sensitive specific ion electrode just prior to analysis. As an internal quality control, primary standard reference material (NIST SRM 3183: Fluoride Anion Standard Solution; National Institute of Standards and Technology, United States) was analyzed. The accuracy was $98 \pm 3 \%$. Water As was analyzed with an Atomic Absorption Spectrophotometer with hydride system (PerkinElmer, model Aanalyst 100, Wellesley, United States). Trace Elements in Natural Water (NIST SRM 1640; National Institute of Standards and Technology, United States) were used for quality control. The accuracy was $99 \pm 2 \%$.

Urine samples were collected in polyethylene bottles the same day as neuropsychological evaluations. F in urine was analyzed according to Method 8308 (Fluoride in Urine) from the National Institute of Occupational Safety and Health 20 . For quality control, the reference standard Fluoride in Freeze-Dried Urine (NIST SRM 2671a; National Institute of Standards and Technology, United States) was analyzed. Accuracy was $97 \pm 6 \%$. For As, urine samples were digested at $70^{\circ} \mathrm{C}$ with a mixture of $\mathrm{HNO}_{3}: \mathrm{HCIO}_{4}$ 1:6. The solution was reduced for $5 \mathrm{~min}$ at $80^{\circ} \mathrm{C}$ with $\mathrm{KI}$ $10 \%$, ascorbic acid 5\%, and $\mathrm{HCl} 21$. As in urine was analyzed using the Atomic Absorption Spectrophotometer with hydride system (PerkinElmer, model Aanalyst 100, Wellesley, United States). For quality control, the reference standard Toxic Metals in Freeze-Dried Urine (NIST SRM 2670; National Institute of Standards and Technology, United States) was analyzed. Accuracy was $98 \pm 4 \%$. Levels of $\mathrm{F}$ and As in urine were adjusted for urinary creatinine levels, which were analyzed with a colorimetric Bayer Diagnostic Kit (Sera-Pak Plus).

To analyzed lead $(\mathrm{Pb})$ exposure, blood samples were obtained by venous puncture using lead-free Vacutainer tubes containing EDTA as an anticoagulant, and were stored at $4{ }^{\circ} \mathrm{C}$ until analysis. $\mathrm{Pb}$ in blood was analyzed with a matrix modifier (Diammonium hydrogenphosphateTriton X-100 in the presence of $0.2 \%$ nitric acid), following Subramanian 22. All analyses were done in duplicate with a Perkin-Elmer 3110 atomic absorption spectrophotometer using a graphite furnace. Distilled-deionized water was used for all analytical work. Glassware and other materials were soaked in $10 \%$ nitric acid, rinsed with doubly distilled water, and dried before use. At the time of analysis, our laboratory participated in the blood lead proficiency testing program conducted by the Centers for Disease Control and Prevention (CDC).

\section{Nutritional and socioeconomic status assessment}

Height and weight by age, as indices of chronic undernutrition, were calculated using reference tables from the U.S. National Center for Health Statistics (NCHS) 23. Z-scores were calculated with the Epi Info program (Centers for Disease Control and Prevention, Atlanta, United States). As indicator of iron status, the percentage of transferrin saturation was calculated by dividing serum iron (SI) concentration by total ironbinding capacity (TIBC) and multiplying by 100 . SI and TIBC were measured with a colorimetric Bayer Diagnostic Kit (Serapack, Bayer). For quality control, Seracheck serum samples were analyzed (Serapack, Bayer). The accuracies for SI and TIBC were $95 \pm 5 \%$ and $92 \pm 4 \%$, respectively.

Socioeconomic status was calculated according to the Bronfman Index. Predictor variables were: household flooring material, crowding, potable water availability, drainage, and father's education ${ }^{24}$. Additional information about type of water used for cooking (tap or bottled), health conditions, etc. were obtained by questionnaire.

\section{Statistical analysis}

This study tested the hypothesis that there is an association between $\mathrm{F}$ and As exposure (measured in urine and in water) and IQ scores (Performance, Verbal, and Full). Bivariate analysis was conducted to analyze differences in means or proportions between the three communities in order to compare exposures and covariates potentially related to the effect of interest (ANOVA followed by pos hoc test, when necessary, and chi-square tests). First, we modeled simple linear regressions for $\mathrm{F}$ or As in urine or in water. Subsequently, we modeled multiple linear regressions including the following variables: $\mathrm{F}$ or As in urine or in water (alone and F-As interaction), blood $\mathrm{Pb}$, mother's education, socioeconomic status, height-for-age $\mathrm{z}$-score, and transferrin saturation. The exposure variables were treated as continuous and the whole data $(n=132)$ were included in regression models. The rationale for this procedure was the following: at the beginning of the study, we selected the three commu- 
nities according their drinking water $\mathrm{F}$ and As concentrations. However, when $\mathrm{F}$ and As in urine values were analyzed, we observed that children in the 5 de Febrero community (with the highest exposure) had urine F or As levels even lower than those of children in Salitral (with medium exposure). This observation is explained by access to bottled water with lower levels of $\mathrm{F}$ or As in the 5 de Febrero community. Some people in this population used tap water for cooking and bottled water for drinking, a practice that served to reduce exposure. Because $\mathrm{F}$ and As in urine levels are better indicators of exposure (because they integrate all sources) and the urine $\mathrm{F}$ and As data from the three communities followed a unimodal distribution, we predicted the outcomes of interest given the exposure variable (F or As in urine) would be continuous for the whole population. Significance level was fixed at 0.05. All analyses were done with SPSS version 12.0 (SPSS Inc., Chicago, United States).

\section{Results}

Sociodemographic characteristics for children from the three communities are presented in Table 1. When comparing the mean concentrations of $\mathrm{F}$ and As in water, statistically significant differences were observed between Moctezuma and both Salitral and 5 de Febrero $(\mathrm{p}<0.001)$. Mean levels of $\mathrm{F}$ in water were almost 3.5 and 6 times higher than WHO limits in Salitral and 5 de Febrero, respectively. Mean levels of As in water were 17 and 19 times higher than WHO limits in Salitral and 5 de Febrero, respectively. No statistically significant differences were observed in participant's age, mother's education, gender proportion, or z-scores (weight-for-age and height-for-age) between the three communities. However, there were statistically significant differences $(\mathrm{p}<0.01)$ in socioeconomic status and proportion of children with transferrin saturation below $20 \%$.

Concentrations of $\mathrm{F}$ and $\mathrm{As}$ in urine and $\mathrm{Pb}$ in blood are shown in Table 2. Mean levels of F in urine were similar for 5 de Febrero and Salitral, but the differences between each of them and Moctezuma were statistically significant. Statistically significant differences in As in urine were observed between Moctezuma and both Salitral and 5 de Febrero. The proportions of children with As in urine levels above the CDC intervention limit were $80 \%$ and $52 \%$ for Salitral and 5 de Febrero, respectively, compared with $3.8 \%$ for Moctezuma. There was a statistically significant difference in mean $\mathrm{Pb}$ levels in blood between 5 de Febrero and Moctezuma. The proportion of children with values above $10 \mu \mathrm{g} / \mathrm{dL}$ ranged from 4.5 to $10 \%$.

To test the association between $\mathrm{F}$ in urine or F in water and IQ scores (Performance, Verbal, and Full), multiple regression models were calculated. Results are shown in Table 3. For F in

Sociodemographic characteristics of children living in three rural areas in Mexico with different levels of fluoride and arsenic in drinking water.

\begin{tabular}{|c|c|c|c|}
\hline & $\begin{array}{c}\text { Moctezuma } \\
(n=52)\end{array}$ & $\begin{array}{l}\text { Salitral } \\
(n=20)\end{array}$ & $\begin{array}{c}5 \text { de Febrero } \\
(n=60)\end{array}$ \\
\hline Water $F(\mathrm{mg} / \mathrm{L})$ * & $0.8 \pm 1.4$ & $5.3 \pm 0.9$ ** & $9.4 \pm 0.9 * *$ \\
\hline Water As $(\mu \mathrm{g} / L)$ * & $5.8 \pm 1.3$ & $169 \pm 0.9 * \star$ & $194 \pm 1.3 * \star$ \\
\hline Age (years) & $8.3 \pm 1.1$ & $7.7 \pm 1.0$ & $8.3 \pm 1.1$ \\
\hline Socioeconomic status * & $7.0 \pm 1.3$ & $6.3 \pm 0.9$ & $5.9 \pm 1.4$ ** \\
\hline Mother's education (years) * & $6.1 \pm 1.7$ & $4.7 \pm 2.0$ & $5.6 \pm 1.7$ \\
\hline Boys (\%) & 54 & 50 & 48 \\
\hline Transferrin saturation $(\%<20) * \star \star$ & $29 * \star$ & $53 * \star$ & 10 \\
\hline Weigh-for-age index $(\%<2 \mathrm{SD})$ \# & 4 & 0 & 0 \\
\hline Height-for-age index $(\%<2$ SD) \# & 0 & 0 & 1.7 \\
\hline
\end{tabular}

* Values are geometric means \pm standard deviation (SD);

** $\mathrm{p}<0.001$

$\star \star \star$ CDC reference level;

\# National Health Survey reference level.

Differences between means were tested with ANOVA. Differences between proportions were evaluated with overall $\chi^{2}$ test. 
Concentrations of fluoride and arsenic in urine and lead in blood of children living in three rural areas in Mexico

(Moctezuma, $\mathrm{n}=52$; Salitral, $\mathrm{n}=20 ; 5$ de Febrero, $\mathrm{n}=60$ ).

\begin{tabular}{|c|c|c|c|}
\hline Mean \pm SD & Minimum-Maximum & Reference value & \\
\hline $\mathrm{F}$ in urine (mg F/gr crt) * & & & $\%>2$ ** \\
\hline Moctezuma & $1.8 \pm 1.5$ & $0.6-4.9$ & 38.5 \\
\hline Salitral & $6.0 \pm 1.6 * * \star$ & $2.9-10.6$ & 100 \\
\hline 5 de Febrero & $5.5 \pm 3.3 * \star \star$ & $1.2-25.0$ & 98 \\
\hline As in urine $(\mu \mathrm{g} \mathrm{As} / \mathrm{g} \mathrm{crt})$ * & & & $\%>50 \#$ \\
\hline Moctezuma & $12.6 \pm 2.0$ & $2.0-7.0$ & 3.8 \\
\hline Salitral & $116 \pm 2.2 * \star \star$ & $26.0-285.0$ & 80 \\
\hline 5 de Febrero & $52.5 \pm 2.2 * \star \star$ & $10.0-325.0$ & 52 \\
\hline $\mathrm{Pb}$ in blood $(\mu \mathrm{g} / \mathrm{dl})$ & & & $\%>10 \# \#$ \\
\hline Moctezuma & $7.1 \pm 2.2$ & $3.0-13.0$ & 10 \\
\hline Salitral & $6.7 \pm 2.1$ & $2.0-10.5$ & 4.5 \\
\hline 5 de Febrero & $4.8 \pm 3.4 * \star \star$ & $0.2-16.0$ & 10 \\
\hline
\end{tabular}

* Geometric means;

** Values measured in areas with levels of fluoride in drinking water less than $1 \mathrm{mg} / \mathrm{L}$;

*** $p<0.001$ compared with Moctezuma;

\# CDC reference value;

\#\# CDC limit for environmental intervention.

Table 3

Multivariable model results for Performance, Verbal, and Full Intelligence Quotient (IQ) by fluoride in urine and water levels, adjusted for confounding variables.

\begin{tabular}{|c|c|c|c|c|c|c|}
\hline \multirow[t]{2}{*}{ Variable } & \multicolumn{2}{|c|}{ Performance IQ } & \multicolumn{2}{|c|}{ Verbal IQ } & \multicolumn{2}{|c|}{ Full IQ } \\
\hline & Water & Urine & Water & Urine & Water & Urine \\
\hline $\log F$ & -7.78 * & $-13.0 *$ & $-11.5 *$ & -16.4 * & $-10.9 *$ & -17.1 * \\
\hline R2 (\%) & 11.1 & 13.4 & 14.7 & 12.9 & 16.7 & 17.4 \\
\hline \multicolumn{7}{|l|}{ Adjusted Model } \\
\hline $\log F$ & $-6.7^{\star}$ & $-13.0 *$ & -11.2 * & $-15.6 *$ & -10.2 * & -16.9 * \\
\hline $\mathrm{Pb}$ blood & -0.45 & -0.52 & -1.0 ** & $-0.94 * \star$ & 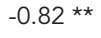 & $-0.83 * \star$ \\
\hline Mother's education & 0.62 & 0.37 & 0.35 & 0.11 & 0.64 & 0.34 \\
\hline Socioeconomic status & 0.60 & 0.13 & 1.23 & 0.92 & 0.94 & 0.47 \\
\hline Height-for-age z-score & 0.74 & 0.74 & 2.9 ** & 3.06 ** & 2.1 & $2.17^{\star *}$ \\
\hline Transferrin saturation & -0.05 & -0.10 & 0.01 & -0.07 & -0.02 & 0.09 \\
\hline Total R2 (\%) & 14 & 17 & 26 & 23 & 25 & 25 \\
\hline
\end{tabular}

$\mathrm{n}=132$

$\star \mathrm{p}<0.001$.

** $\mathrm{p}<0.05$

urine, the coefficients ( $\beta$ values) for Performance, Verbal, and Full IQ scores, adjusted for Pb blood, socioeconomic status, mother's education, height-for-age z-score, and transferrin saturation, were $-13.0,-15.6$, and -16.9 , respectively (all $\mathrm{p}$ values $<0.001)$. For $\mathrm{F}$ in water, the coefficients ( $\beta$ values), also adjusted for the same confounders mentioned above, were $-6.7,-11.2$, and -10.2 , respectively (all $\mathrm{p}$ values $<0.001$ ).
As exposure data are shown in Table 4. After adjusting for confounders ( $\mathrm{Pb}$ blood, socioeconomic status, mother's education, height-for-age $\mathrm{z}$-score, and transferrin saturation), As in urine was found to be inversely associated with Full IQ scores $(\beta=-5.72, p=0.003)$. We also observed inverse relationships for Performance and Verbal IQ scores, however they were not as significant $(\beta=-4.19, p=0.08 ; \beta=-5.50, p=0.06$, respective- 
Multivariable model results for Performance, Verbal, and Full intelligence quotient (IQ) by arsenic in urine and water levels, adjusted for confounding variables.

\begin{tabular}{|c|c|c|c|c|c|c|}
\hline \multirow[t]{2}{*}{ Variable } & \multicolumn{2}{|c|}{ Performance IQ } & \multicolumn{2}{|c|}{ Verbal IQ } & \multicolumn{2}{|c|}{ Full IQ } \\
\hline & Water & Urine & Water & Urine & Water & Urine \\
\hline Log As & -5.17 * & -5.3 ** & $-7.19 *$ & $-6.9 *$ & -7.09 * & $-7.1 *$ \\
\hline $\mathrm{R}^{2}(\%)$ & 10.9 & 4.8 & 12.8 & 5.0 & 15.3 & 6.5 \\
\hline \multicolumn{7}{|l|}{ Adjusted model } \\
\hline $\log A s$ & -4.30 * & -4.19 & $-6.40 *$ & -5.50 & $-6.15 *$ & -5.72 ** \\
\hline $\mathrm{Pb}$ blood & -0.37 & -0.25 & -0.84 ** & -0.63 & -0.68 & -0.49 \\
\hline Mother's education & 0.51 & 0.64 & 0.20 & 0.42 & 0.49 & 0.69 \\
\hline Socioeconomic status & 0.68 & 0.63 & 1.43 & 1.46 & 1.01 & 1.07 \\
\hline Height-for-age z-score & 0.70 & 0.91 & $2.90 * \star$ & 3.26 ** & 2.08 & $2.39 * *$ \\
\hline Transferrin saturation & -0.06 & -0.11 & -0.005 & -0.75 & -0.03 & 0.10 \\
\hline Total R2 (\%) & 13.5 & 9.5 & 23.5 & 17.2 & 22.8 & 16 \\
\hline
\end{tabular}

$n=132$.

${ }^{*} \mathrm{p}<0.01$

$* * p<0.05$.

ly). After adjusting for confounders, As in water showed inverse associations with Performance, Verbal, and Full IQ scores $(\beta$ values $=-4.30,-6.40$, and -6.15 , respectively; all $p$ values $<0.001$ ).

\section{Discussion}

We found that exposure to $\mathrm{F}$ in urine was associated with reduced Performance, Verbal, and Full IQ scores before and after adjusting for confounders $(\beta$ values $=-13.0,-15.6$, and -16.9 , respectively; all $\mathrm{p}$-values $<0.001$ ). The same pattern was observed for models with $\mathrm{F}$ in water as the exposure variable $(\beta$ values $=-6.7,-11.2$, and -10.2 , respectively; all $\mathrm{p}$-values $<0.001$ )

The impact of F on IQ has been reported in several studies by Chinese researchers. In one study conducted in 1995, mean IQ scores were compared between children living in areas with different prevalence of dental fluorosis. The mean IQ score of residents in the severe fluorosis area (mean urinary $\mathrm{F}$ of $2.69 \mathrm{mg} / \mathrm{L}$ and index of dental fluorosis of 3.2) was 80.3 points, whereas in the low fluorosis area (mean urinary $\mathrm{F}$ of $1.02 \mathrm{mg} / \mathrm{L}$ and index of dental fluorosis < 0.4 ) it was 89.9 points. The difference between groups was statistically significant 9 . Another study compared IQ scores between children living in two villages with different mean levels of $F$ in water $(4.12 \mathrm{mg} / \mathrm{L}$ vs. $0.91 \mathrm{mg} / \mathrm{L})$. Although the authors did not control for confounding factors and did not measure $\mathrm{F}$ in urine, they report that the average IQ of children in the high fluoride area (97.69 points) was significantly lower than in the low fluoride area (105.21 points) 10. The two studies just mentioned used the Rui Wen Test to measure IQ. In 2000, another report compared IQ scores for children from two areas in China (F in drinking water $3.15 \mathrm{mg} / \mathrm{L}$ vs. $0.37 \mathrm{mg} /$ $\mathrm{L}$ ). They also measured the concentration of $\mathrm{F}$ in urine (mean urinary F of $4.99 \mathrm{mg} / \mathrm{L}$ vs. $1.43 \mathrm{mg} /$ L). The mean IQ score for children in the more exposed area (92.2 points) was lower than for children living in the less exposed area (103.05 points) 11 . Finally, another Chinese study evaluated 118 children from two villages. The mean IQ score for the high-fluoride area (92.02 points; $\mathrm{F}$ in water $2.47 \mathrm{mg} / \mathrm{L}$ ) was significantly lower than for the low-fluoride area ( 100.41 points; $F$ in water $0.36 \mathrm{mg} / \mathrm{L})$. In this study, a mild inverse association between $\mathrm{F}$ in urine and IQ scores $(\mathrm{r}=$ $-0.17, \mathrm{p}=0.003$ ) was reported. No adjustment was made for confounders 12. Despite having several shortcomings (lack of adjustment for confounders, no biological markers, no quantification of other potential neurotoxic pollutants, etc.), all of these studies suggest that F negatively impacts IQ scores, with observed reductions in IQ ranging from 8 to 11 points between exposed and non-exposed children.

The levels of children's exposure to $\mathrm{F}$ in the present study were higher than in the Chinese studies. F in drinking water was 3.5 and 6 times higher than the WHO reference guideline for two of the communities. On average, the value of $\mathrm{F}$ in urine was $6.6 \mathrm{mg} / \mathrm{g}$ crt. Additionally, more than $50 \%$ of the children in the two high exposure 
areas had As in urine above the CDC reference value of $50 \mu \mathrm{g} / \mathrm{g}$ crt. The individual effect of $\mathrm{F}$ in urine indicated that for each $\mathrm{mg}$ increase of $\mathrm{F}$ in urine a decrease of 1.7 points in Full IQ might be expected. The proportion attributable to $\mathrm{F}$ in urine alone was $17 \%$ above the contribution of other measured factors. The variance in Full IQ explained in the adjusted model was $25 \%$. Regarding As in urine, we observed an inverse association with Full IQ scores ( $\beta=-5.72, p=0.003$ ). We also observed an inverse relationship for Performance and Verbal IQ scores, although with less significance $(\beta=-4.19, \mathrm{p}=0.08 ; \beta=-5.50$, $\mathrm{p}=0.06$, respectively). We also found that As in water was inversely correlated with Performance, Verbal, and Full IQ scores $(\beta$ values $=-4.30,-6.40$, and -6.15 ; all $p$ values $<0.001$ ). Compared to $F$, the effect attributable to As was smaller.

There are also data in the literature supporting the possible role of As in IQ reduction. In one study conducted by our group, a negative association was observed between urinary As (mean = $62.9 \mu \mathrm{g} / \mathrm{g}$ crt $)$ and Verbal $(\mathrm{r}=-0.43, \mathrm{p}=0.008)$ and Full IQ scores $(r=-0.33, p=0.04)$, after adjustment for confounders, in children living around a smelter complex 15. Another study conducted in Bangladesh reported an inverse association between water As and Performance and Full IQ scores $(\beta$ values $=-1.45$ and -1.64 , respectively; $\mathrm{p}<0.001$ in both cases) 13 .

The adverse effects of $\mathrm{F}$ and As on the human central nervous system are supported by experimental data. When F crosses the blood brain barrier, the hematoencephalic barrier, it accumulates in the brain, inducing structural and cognitive alterations in the central nervous system 17,25. Rats exposed to $\mathrm{F}$ in drinking water at weaning had elevated fluoride levels in 6 of 7 brain regions and plasma fluoride levels 7 to 42 times higher than those found in control animals. These elevated plasma and brain F levels were associated with behavior alterations, such as cognitive deficits 17 . Learning deficits in a delayed alternation task and alterations in a spatial learning task have been reported for groups exposed to As as compared to control groups 18,26,27.

The design of the present study precluded testing statistically the interaction between $\mathrm{F}$ and As. However, a previous study conducted by our research group in the city of San Luis Potosí, IQ scores were evaluated using WISC-RM in a population of children exposed to $\mathrm{F}$ in drinking water (values ranged from 1.5 to $3 \mathrm{mg} / \mathrm{L}$ ). The mean levels of $\mathrm{F}$ and As in urine were $4.3 \pm 1.5 \mathrm{mg} / \mathrm{g}$ crt and $41 \pm 1.5 \mu \mathrm{g} / \mathrm{g}$ crt, respectively. This study did not demonstrate any effect on IQ scores, but did show a positive relationship between $\mathrm{F}$ in urine and reaction time $(r=0.28, p=0.04)$ and an in- verse relationship between $\mathrm{F}$ in urine and visualspatial organization scores $(r=-0.27, p=0.05) 16$. These data may lend support to the hypothesis that exposure to both toxicants could worsen children's performance on neuropsychological tests and thus indicates the need for further investigation.

Our results regarding $\mathrm{Pb}$ in blood indicate that the observed deficits in IQ scores cannot be attributed to $\mathrm{Pb}$ exposure. When $\mathrm{Pb}$ in blood was included in the adjusted model for F in urine, the correlation remained significant with only a small contribution to the variance, whereas, in the adjusted model for As in urine, it was not significant.

Although this was a cross-sectional study and $\mathrm{F}$ and As in urine are biomarkers of recent exposure, we have data about past exposures for two of the communities included in this study. In 5 de Febrero, levels of $F$ in water reported from 1997 to 2004 ranged from $8.7 \mathrm{mg} / \mathrm{L}$ to $10.2 \mathrm{mg} / \mathrm{L}$. As values for the same period ranged from $130 \mu \mathrm{g} / \mathrm{L}$ to $215 \mu \mathrm{g} / \mathrm{L}$. Levels of both pollutants in water were above WHO standards. Data for Salitral from 2002 and 2003 show that $F$ levels were on average $5.3 \mathrm{mg} / \mathrm{L}$ and As ranged from $141 \mu \mathrm{g} /$ L to $150 \mu \mathrm{g} / \mathrm{L}$. Although we do not have historical data regarding levels of $\mathrm{F}$ in water in Moctezuma, we can assume that they were similar to our findings because none of the children had dental fluorosis, an indicator of chronic exposure to F. Based on this information and because $F$ and As in water were highly correlated $(\mathrm{r}=0.86, \mathrm{p}<$ 0.001 ), we assume that the exposure scenario has not changed over time and the current exposure to F or As in drinking water can be used as a proxy for past exposure. Some of the effects on brain dysfunctions are observed years after exposure. The children in the study sample were exposed since birth and remained exposed until the study data were collected. Biological levels of $\mathrm{F}$ and As are clearly better indicators of actual exposure because they integrate all sources and changes in exposure. Fifty-three percent of people from 5 de Febrero reported using bottled water for drinking but not for cooking, whereas this figure was $27 \%$ for the Salitral community.

In conclusion, the data from this research support the conclusion that $\mathrm{F}$ and As in drinking water have a potential neurotoxic effect in children. It is urgent that public health measures to reduce exposure levels be implemented. Millions of people around the world are exposed to these pollutants and are therefore potentially at risk for negative impact on intelligence. This risk may be increased where other factors affecting central nervous system development, such as malnu- 
trition and poverty, are also present. The risk is particularly acute for children, whose brains are particularly sensitive to environmental toxins.
Furthermore, it would be advisable to reexamine the benefits of $\mathrm{F}$ given the documented health risks.

\section{Resumen}

Estudios recientes sugieren que el flúor $(F)$ y el arsénico (As) pueden tener efectos adversos sobre el coeficiente intelectual (CI). En este estudio exploramos la asociación entre el Fy el As y la inteligencia en niños expuestos a estas sustancias a través del agua. Tres comunidades rurales de México con diferentes niveles de F y As fueron estudiadas: Moctezuma (F 0,8 $\pm 1,4 \mathrm{mg} / \mathrm{L}$;

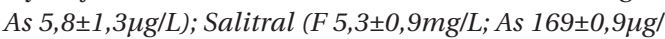
L) y 5 de Febrero (F 9,4 $\pm 0,9 \mathrm{mg} / \mathrm{L}$; As $194 \pm 1,3 \mu \mathrm{g} / \mathrm{L}$ ). La muestra final fue de 132 niños de 6 a 10 años de edad. Después de controlar por confusores, se obtuvieron asociaciones inversas entre F en orina y las puntuaciones de los CI (Desempeño, Verbal y Total) (valores $\beta=$ $-13,-15,6,-16,9$, respectivamente) $p<0,001$ en todos los casos. Resultados similares se obtuvieron con $F$ en agua (valores $\beta=-6,7,-11,2,-10,2$, respectivamente) y con As en agua (valores $\beta=-4,30,-6,40,-6,15$, respectivamente). En todos los casos $p<0,001$. Para As en orina, se obtuvo una asociación inversa con las puntuaciones del CI total $(\beta=-5,72 ; p=0,003)$. Estos datos sugieren que los niños expuestos al Fo al As tienen mayor riesgo de tener disminución en las puntuaciones del CI.

Fluoruros; Arsénico; Agua Potable; Neurotoxinas; Inteligencia

\section{Contributors}

D. Rocha-Amador participated in urine and water sampling, questionnaire application, quantification of fluoride in water and urine, quantification of creatinine in urine, quantification of blood iron levels, database development, and data analysis. L. Carrizales participated in blood sampling, quantification of lead in blood and arsenic in urine and water, and questionnaire application. M. E. Navarro and R. Morales contributed to the application and evaluation of neuropsychological tests. J. Calderón was responsible for project design, procuring financial resources, statistical analysis of data, and final writing of the article.

\section{Acknowledgements}

This work was supported by Consejo Nacional de Ciencia y Tecnología - CONACYT (Proyect J 37584-M). We are grateful to Dr. Díaz-Barriga for helpful comments on the manuscript. 


\section{References}

1. World Health Organization. Guidelines for drinking water quality. v. 1: recommendations. http:// www.who.int/water_sanitation_health/dwq/ gdwq3/en/ (accessed on 03/Sep/2006).

2. México. Modificación a la Norma Oficial Mexicana NOM-127-SSA1-1994. Salud ambiental, agua para uso y consumo humano. Límites permisibles de calidad y tratamientos a que se debe someterse el agua para su potabilización. Diario Oficial 2000; Primera sección, p. 48-54.

3. Smedley PL, Kinninburg DG. A review of the source, behaviour and distribution of arsenic in natural water. Applied Geochemistry 2002; 17:51768.

4. Méndez M, Armienta MA. Arsenic phase distribution in Zimapán mine tailings, México. Geofísica Internacional 2003; 42:131-40.

5. Trejo R, Alarcón MT, Martínez Y, Romero P, Salvador J. Niveles de fluoruros en el agua de los pozos de la ciudad de Durango. Ingeniería Hidráulica en México 1997; 12:51-7.

6. Díaz-Barriga F, Leyva R, Quistián J, Loyola-Rodríguez JP, Pozos A, Grimaldo M. Endemic fluorosis in San Luis Potosi, Mexico. IV. Sources of fluoride exposure. Fluoride 1997; 30:219-22.

7. Centers for Disease Control and Prevention. Review of fluoride "benefits and risks". Washington DC: U.S. Department of Health and Human Services; 1991

8. Yoshida T, Hiroshi Y, Fan Sun G. Chronic health effects in people exposed to arsenic via drinking water: dose-response relationship in review. Toxicol Appl Pharmacol 2004; 198:243-52.

9. Li XS, Zhi JL, Gao RO. Effect of fluoride exposure on intelligence in children. Fluoride 1995; 28:18992.

10. Zhao LB, Liang GH, Zhang DN, Wu XR. Effect of a high fluoride water supply on children's intelligence. Fluoride 1996; 29:190-2.

11. Lu Y, Sun ZR, Wu LN, Wang X, Lu W, Liu SS. Effects of high-fluoride water on intelligence in children. Fluoride 2000; 33:74-8.

12. Xiang Q, Liang Y, Chen L, Wang C, Chen B, Zhou M. Effects of fluoride in drinking water on children's intelligence. Fluoride 2003; 36:84-94.

13. Wasserman GA, Liu X, Parvez F, Ahsan H, FactorLitvak P, van Geen A, et al. Water arsenic exposure and children's intellectual function in Araihazar, Bangladesh. Environ Health Perspect 2004; 112:1329-33.

14. Tsai SY, Chou HY, The HW, Chen CM, Chen CJ. The effects of chronic arsenic exposure from drinking water on the neurobehavioral development in adolescence. Neurotoxicology 2003; 24:747-53.
15. Calderón J, Navarro ME, Jiménez-Capdeville ME, Santos-Díaz MA, Golden A, Rodríguez-Leyva I, et al. Exposure to arsenic and lead and neuropsychological development in Mexican children. Environ Res 2001; 85:69-76.

16. Calderón J, Machado B, Navarro ME, Carrizales L, Díaz-Barriga F. Influence of fluoride on reaction time and organization visuospatial in children. Epidemiology 2001; 11:S153.

17. Mullenix JP, Denbesten PK, Schunior A, Kernan WJ. Neurotoxicity of sodium fluoride in rats. Neurotoxicol Teratol 1995; 17:169-77.

18. Rodriguez VM, Jímenez-Capdville ME, Giordano $M$. The effects of arsenic exposure on the nervous system. Toxicol Lett 2003; 145:1-18.

19. Gómez-Palacio M, Padilla E, Roll S. Escala de Inteligencia revisada para el nivel escolar (WISC-RM): manual de aplicación adaptado y estandarizado en México. México DF: Editorial Manual Moderno; 1993.

20. National Institute for Occupational Safety and Health. Manual of analytical methods. 3rd Ed. Atlanta: Centers for Disease Control and Prevention; 1984.

21. Cox DH. Arsine evolution-electrothermal atomic absorption method for the determination of nanogram levels of total arsenic in urine and water. J Anal Toxicol 1980; 4:207-11.

22. Subramain KS. Determination of lead in blood: comparison of two GFAAS methods. Atom Spectrosc 1987; 8:7-14.

23. Dibley MJ, Goldsby JB, Staehling NW, Trowbridge FL. Development of normalized curves for the international growth reference: historical and technical considerations. Am J Clin Nutr 1987; 46:73648.

24. Bronfman MG, Castro H, Gutiérrez G. Medición de la desigualdad: una estrategia metodológica, análisis de las características socioeconómicas de la muestra. Arch Invest Med (Mex) 1998; 19:35160.

25. Varner JA, Karl F, Horvarth JW, Issacson RL. Chronic administration of aluminium-fluoride or sodium-floride to rats in drinking water: alterations in neuronal and cerebrovascular integrity. Brain Res 1998; 784:284-98.

26. Rodriguez VM, Carrizales L, Jimenez-Capdeville ME, Dufour L, Giordano M. The effects of sodium arsenite exposure on behavioral parameters in the rat. Brain Res Bull 2001; 55:301-8.

27. Rodriguez VM, Carrizales L, Mendoza MS, Fajardo OR, Giordano M. Effects of sodium arsenite exposure on development and behaviour in the rat. Neurotoxicol Teratol 2002; 24:743-50.

Submitted on 02/May/2006

Final version resubmitted on 11/Sep/2006

Approved on 10/Oct/2006 